\title{
Applying The "Cognitive Conflict" Strategy To Facilitate Changes in The Conception of First Semester Students on The Topic of Voltaic Cell
}

\author{
Omay Sumarna \\ Department of Chemistry Education \\ FPMIPA UPI Bandung \\ ${ }^{1}$ sumarna@hotmail.com
}

\author{
Risma Yulistiana \\ Department of Chemistry Education \\ FPMIPA UPI Bandung
}

\begin{abstract}
The main objective of this study was to obtain the information regarding freshman students' alternative conceptions, the characteristics of conflict cognitive strategy and the profile of students' conceptual change in Voltaic Cell, which were further elaborated into six determined indicators. The subject consisted of fourteen freshman students of Chemistry Programme. This study was conducted into three stages, which were (1)pre-test, (2)cognitive conflict instruction and (3) post-test. Students' conceptions profile were classified into three categories based on Appleton, 1999 (Rolka, 2007), which were identical fit, approximate fit and incomplete fit. Based on the data obtained from the pretest, students generally performed the incomplete fit and approximate fit for all indicators, but only a few performed the identical fit. The characteristics of conflict cognitive strategy that is able to facilitate students' conceptual change was those that destabilize students' inaccurate existing conception through contradictory experiences (disequilibrium), followed by teacher's intervention that enables the students rich the reequilibrium. After the instruction, students generally performed the raising conception profile, but some did not perform conceptual change and only a few performed the lowering one.
\end{abstract}

Keywords - conception; cognitive conflict; conceptual change; incomplete fit; approximate fit and identical fit

\section{INTRODUCTION}

In general, students learning in the classroom are not in a blank state. Instead, they have brought a number of experiences and ideas that are formed from previous interactions with the environment (Pinker, 2003). Duit (2002) says that the initial conception of the students is not generally accepted in accordance with the concept of the experts. Kutluay (2005) says that conception is incompatible with the conception of which scientists called as alternative conceptions. According Driver (Khurshid, 2009), it can be sourced from alternative conceptions of learning in school, out of school learning, everyday experiences, social environment, and intuition.
Based on the experience of a lecturer in Basic Chemical class, the findings obtained alternative conceptions of first semester students on the topic of Volta cells. This topic is the first topic they learned in the course Basic Chemistry II. The first semester students have studied topics of Volta cells in high school However, some research suggests the findings related to alternative conceptions on this topic. Sanger and Greenbowe (1999) conducted an analysis of several chemistry textbooks as the sources of the emergence of alternative conceptions and learning difficulties in electrochemical materials. Ozkaya et al (2003) found that teachers also have alternative conceptions regarding electrochemical materials. Dindar et al (2010) also found alternative conceptions of teachers on the topic Volta cells, namely the salt bridge subtopics.

Klammer (1998) states that alternative conception is very resistant to change (Kutluay, 2005). If the alternative conceptions have been entered into the cognitive structure of students, then the alternative conception will hinder the process of acceptance and assimilation of new knowledge that would hinder the success of students in the further learning process (Toka and Askar, 2002). Therefore, we need learning conditions that can change the alternative conceptions into scientific conception through learning to be more necessary, intelligible, plausible, and fruitful (Posner, 1982).

According to Piaget (Hergenhahn and Olson, 2009), humans have an internal need to be in a state of balance between understanding the cognitive experience. When individuals experience imbalance (disequilibrium) between perception and experience, this situation motivates individuals to solve the conflict. Piaget called the process of solving this conflict as re-equilibrium, which is defined as the process of setting the self (selfregulation) in response to stimuli from the environment and adjust to the new experiences that fit into existing cognitive structures (assimilation) and structural improvements for the adjustment of new data (accommodation) 
As previously stated by Posner and Piaget, one of the learning strategies that can be used to facilitate change students' conceptions of alternative conceptions towards a scientific conception is cognitive conflict. Johnson and Johnson (Lee, 2003) suggests that this learning is conditioned by presenting different views or disagreement between students and students or between teachers and students to develop a deeper knowledge. Lee (2001) says that a cognitive conflict is not only characterized by feeling of doubt, dissatisfied, wonder, and interested or agitated, but can also result in destructive if students are frustrated.

Rolka (2007) describes and analyzes the students' conceptions profiles submitted by Appleton (1997) during the learning of science. This conception profile model in accordance with the terms of assimilation and accommodation Piaget and analyze the possibility that occurs when students meet the new information and experiences. When this information is processed, the development of conflict situations can be described into three possibilities as follows:

\section{Identical fit}

The new information received in complete agreement with prior knowledge that has been owned. Students are able to understand the new information with prior knowledge base they have. However, this does not mean that the explanation given by the students are correctly complete.

\section{Approximate fit}

The new information received by the students associated with prior knowledge they have, but the details of the new knowledge is not clearly linked. The students acquire new ideas, but still engage old ideas that have been previously acquired. Although contradictory, the students do not achieve cognitive conflict situations. Therefore, the new information is assimilated but not accommodated in students' thinking.

\section{Incomplete fit}

The stated new information does not match the students with the expected thought. This information which does not match generates cognitive conflict. When students experience a state of incomplete fit, they tried to reduce conflict by seeking information that may be used as a solution.

\section{RESEARCH METHODS}

This study uses a pre-experiment one group pre-test post-test design. 14 first semester students were given the initial ability test to obtain early conception student profile data. The initial conception of student profiles is taken into consideration in formulating Learning Implementation Plan. Treatment of cognitive conflict strategies is made using practical methods, expository, and discussion. Then, the students were given the final ability test to obtain the end of the conception of the student profile data after.

\section{RESULTS AND DISCUSSION}

Based on the initial test results and test the ability of end capabilities, overall there is no student who had no conception at all (no conception) because they have studied the topic Volta cells while still in high school. Interviews showed that prior to the initial ability test, the students not only learn topics Volta cells in high school, but they also taught themself by reading books and enrichment articles, encyclopedias, science magazines, and discussions with their peers. Therefore, in this study the students has brought a number of conceptions on the topic Volta cells based on their experiences while studying in high school and supplemented by self-taught learning.

There are 6 indicators developed in this study, namely:

1. Determining the spontaneity of oxidation-reduction reaction by Volta series.

2. Determining spontaneous oxidation-reduction reaction that can be used to generate electric current.

3. Determining the circuit which can produce oxidation - spontaneous reduction to generate electric current.

4. Distinguishing oxidation - spontaneous reduction in the circuit without dividing cells and cell Volta Volta with separators.

5. Distinguishing oxidation - spontaneous reduction in the circuit without salt bridge Volta cells and cell Volta with salt bridge.

6. Identifying positive and negative poles of Volta cells based on the direction of the flow of electrons that occurs.

\section{A. Students Conception Profile on Initial Ability Test}

Based on Figure 1, it is known that generally the students are in the category of incomplete and approximate fit. There are only a small proportion of students who are in the category of identical fit.

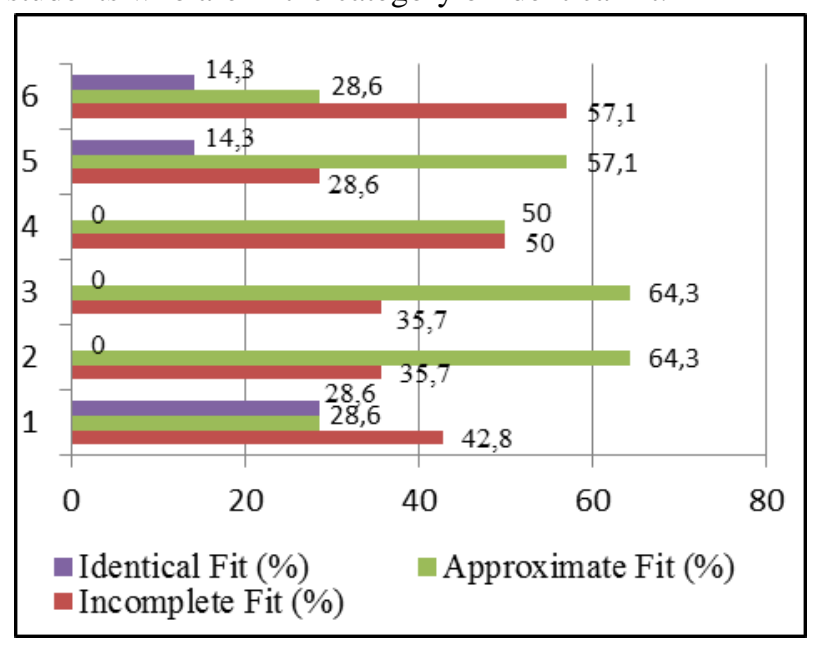

Fig. 1. Students Conception Profile on Initial Ability Test

\section{B. TREATMENT OF LEARNING}

In general, treatment of learning follows the path shown in Figure 2. The given treatment uses practical methods, expository, and discussion. By the time the lab, not done weighing the mass of electrodes, but only based on changes that can be observed directly by the students. Students were divided into seven groups, each group consisting of two people. The division of the group announced at the initial ability based on their scores on the initial test of Basic Chemistry 2, which includes high school material on thermochemical, kinetics, chemical equilibrium, and electrochemistry. Therefore, each group can be assumed to have almost the same distribution 
capabilities. Each student is given an MFI which contains guidelines experiment to answer the problem (questions) on the initial ability test and the end ability test.

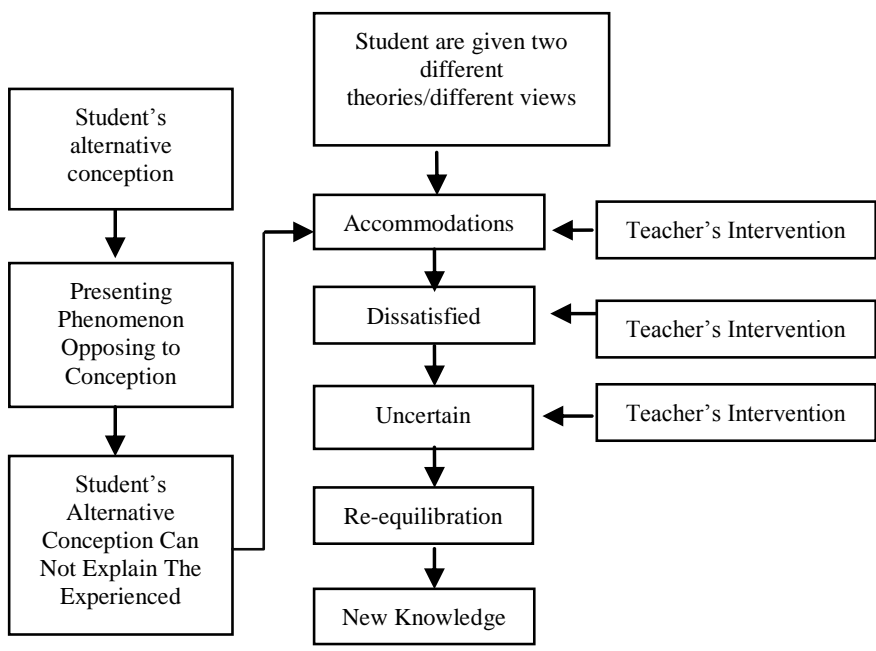

Fig. 2. Process Flowchart of Cognitive Conflict Learning

\section{1) Treatment in Indicator 1}

Students perform four experiments are shown in Figure 3. In systems 1 and 3, the blue color fades $\mathrm{CuSO}_{4}$ solution and on the surface of $\mathrm{Zn}$ precipitation is originally black, but later became a reddish brown.



Fig. 3. Experiment 1-4

Some students initially assume that the black color is because they never saw $\mathrm{CuOCuO}$ black when in high school. One of the students said that the $\mathrm{CuO}$ formed from the reduction of $\mathrm{Cu} 2+$ into $\mathrm{Cu}, \mathrm{Cu}$ then react with $\mathrm{O}_{2}$ in the air. Researchers showed that $\mathrm{Cu}$ is left for more than three hours in the open air did not give a black color, which means that the reaction of $\mathrm{Cu}$ with less oxygen in the air does not happen quickly. Some students become hesitant with their initial answers. Lee (2001) said that doubts about their own answers are characteristic that they experience cognitive conflict situations. Then, researchers intervened in the form of questions given by mentor until they conclude that the precipitate formation on metal surfaces $\mathrm{Zn} \mathrm{Cu}$ occurs gradually in which its previous color were black that marks the beginning of this precipitate absorbs energy at all wavelengths of visible light. When the $\mathrm{Cu}$ precipitate formed already started excessive, then there is a certain amount of energy after the energy emitted at all wavelengths are absorbed. The energy emitted is in the brownish-red color wavelength (480-500 $\mathrm{nm})$.

\section{Treatment of the indicators 2 and 3}

Students conduct experiments shown in Figures 4 and 5. In the system $5, \mathrm{Zn}$ and $\mathrm{Cu}$ electrode is dipped into a solution of $0.1 \mathrm{M} \mathrm{CuSO}_{4}$ Both electrodes are in the same container and connected by an external circuit and multimeter.

System 5 generates a potential difference measured in multi-meter, the blue color fades $\mathrm{CuSO}_{4}$ solution, and the reddish-brown precipitate is formed on the surface of the electrode $\mathrm{Cu}$ and $\mathrm{Zn}$.

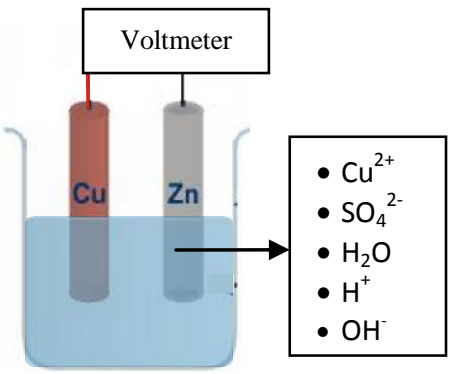

Fig. 4. System 5

Some students revealed the expression of interest and anxiety because of the results of their experiments are in contrast to the theory they learned from high school books. This interest and anxiety situations, according to Lee (2001) is a hallmark of cognitive conflict. Most of the students argue there should be no electric current occurs so the multi-meter needle should not move because in the system 5 the whole the ejected electrons from the oxidation reaction of $\mathrm{Zn}$ was used to reduce the surface $\mathrm{Zn} \mathrm{Cu}^{2+}$. Most of the other students found no electric current that is generated, but only for a moment so that the multimeter needle should immediately return to zero. Those, who argue that there is momentary electric current that is generated, say that the electrolyte solution in system 5 experiences the non-neutrality charge. There also were found metal $\mathrm{Zn}$ coated with $\mathrm{Cu}$ that cannot oxidize again. Another student is not certain toward the identity of the anode and cathode in this circuit and could not explain why the zinc which is apparently anode also be a reduction reaction.

Researchers guide students through the questions until they conclude that the electrons that are released on the system 5 can experience two things, namely:

1. Electron of $\mathrm{Zn}$ oxidation products flows through the outer circuit toward $\mathrm{Cu}$ due to the potential difference between $\mathrm{Zn}$ and $\mathrm{Cu}$. Electrons flow through an external circuit to generate electric current. Because the electrons flow toward $\mathrm{Cu}$, the $\mathrm{Cu}^{2+}$ around the surface of the $\mathrm{Cu}$ captures electrons and form deposits on the surface of $\mathrm{Cu}$.

2. There are also electrons which could not flow through an external circuit due to direct electrons captured by $\mathrm{Cu}^{2+}$ ions are located around the surface of $\mathrm{Zn}$. As a result, the reduction of $\mathrm{Cu}^{2+}$ can also occur on the surface of $\mathrm{Zn}$.

With the guidance of researchers through the questions, the students concluded that in the system 5 the non-neutrality charge does not occur because each $\mathrm{Zn}^{2+}$ that is formed is always followed by the reduced $\mathrm{Cu}^{2+}$.

Researchers say that the electrolyte solution used in this experiment has a low concentration $(0.1 \mathrm{M})$, ten times more dilute than the standard state $(1 \mathrm{M})$. With the 
questions of supervisor of researchers, students concluded that the more concentrated electrolyte solution concentration, the oxidation - reduction is faster and $\mathrm{Zn}$ surface quickly covered by $\mathrm{Cu}$ sediment so $\mathrm{Zn}$ cannot undergo further oxidation reaction. However, in the lower electrolyte solution concentration, the surface of $\mathrm{Zn}$ did not immediately covered by $\mathrm{Cu}$ sediment so that the electric current produced can last longer.

Furthermore, in the system $6, \mathrm{Zn}$ and $\mathrm{Cu}$ electrode is dipped into a solution of $0.1 \mathrm{M} \mathrm{ZnSO}_{4}$ Both electrodes are in the same container and connected by an external circuit and multimeter.

System 6 generates a potential difference measured in multimeter and bubbles formed around the surface of the electrode $\mathrm{Zn}$ and $\mathrm{Cu}$.

Most of the students become uncertain to the theory which they have learned and others doubt the outcome of their trial. According to them, should the system 6 can not produce oxidation - spontaneous reduction.

Fig. 5. System 6

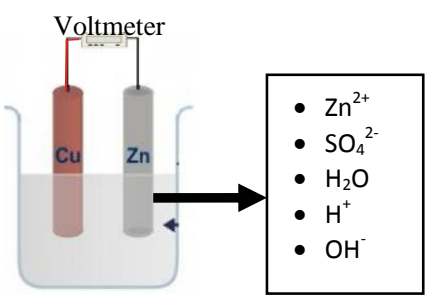

Researchers guide students through the questions until they conclude that $\mathrm{Zn}^{2+}$ ions in the water undergoes partial hydrolysis reactions produce ion $\mathrm{H}_{3} \mathrm{O}^{+}$.

$$
\mathrm{ZnSO}_{4(\Omega)} \mathrm{Zn}_{2(a q)}+\mathrm{H}_{2} \mathrm{O} \rightarrow \mathrm{Zn}_{(a q)}^{2+}+\mathrm{SO}_{4(a q)}^{2-}
$$

$\mathrm{Zn}^{2+}$ ions in water are the most stable in the form of complex $\left[\mathrm{Zn}\left(\mathrm{H}_{2} \mathrm{O}\right)_{6}\right]^{2+}$.

$$
[\mathrm{Zn}(\mathrm{H} 2 \mathrm{O}) 6]_{(a q)}^{2+}+\mathrm{H}_{2} \mathrm{O}_{(\mathrm{D})} \leftrightarrows\left[\mathrm{Zn}\left(\mathrm{H}_{2} \mathrm{O}\right)_{5} \mathrm{OH}\right]_{(a q)}^{+}+\mathrm{H}_{\mathrm{a}} \mathrm{O}^{+}
$$

With the hydrolysis reaction to this, the number of ion $\mathrm{H}_{3} \mathrm{O}+$ or $\mathrm{H}+$ which is in solution becomes more and more because of $\mathrm{H}+$ is now not only generated from ionization reaction of water, but also from the hydrolysis reaction. This is evident from the blue litmus paper turns red when it is dipped into a solution of $\mathrm{ZnSO}_{4}$.

With questions supervisor of researchers, students concluded that based on the series Volta, metal $\mathrm{Zn}$ and $\mathrm{H}^{+}$ions can undergo oxidation reaction - spontaneous reduction as follows:

$$
\begin{array}{ll}
\mathrm{Zn}(s) & \rightarrow \mathrm{Zn}^{2+}(a q)+2 e \\
2 \mathrm{H}^{+}(a q)+2 e & \rightarrow \mathrm{H}_{2}(g) \\
\mathrm{Zn}(s)+2 \mathrm{H}^{+}(a q) \rightarrow \mathrm{Zn}^{2+}(a q)+\mathrm{H}_{2} & (g)
\end{array}
$$

With the supervisor questions regarding the movement of electrons and concentration as in 5 above system, students can infer why the system 6 can generate electric currents and bubbles are formed around the surface of the metal $\mathrm{Zn}$ and $\mathrm{Cu}$.

On these indicator 2 and 3, there are a small portion of students who are aware of the situation of cognitive conflict, but are not interested in resolving the conflict because they think this matter is too confusing. This is consistent with the findings of Lee (2001) that cognitive conflict can be destructive if students feel frustrated. Therefore, teacher intervention is indispensable not only to make students aware of the situation of cognitive conflict, but also to enable students to resolve conflicts (re-equilibrium).

\section{Treatment of Indicators 4}

Students conduct experiments 5 and 7. At system7, $\mathrm{Zn}$ electrode is dipped into a solution of $0.1 \mathrm{M} \mathrm{ZnSO}_{4}$ and $\mathrm{Cu}$ electrode is dipped into a solution of $0.1 \mathrm{M}$ $\mathrm{CuSO}_{4}$ in two different containers. Both electrodes are connected by an external circuit and multimeter.

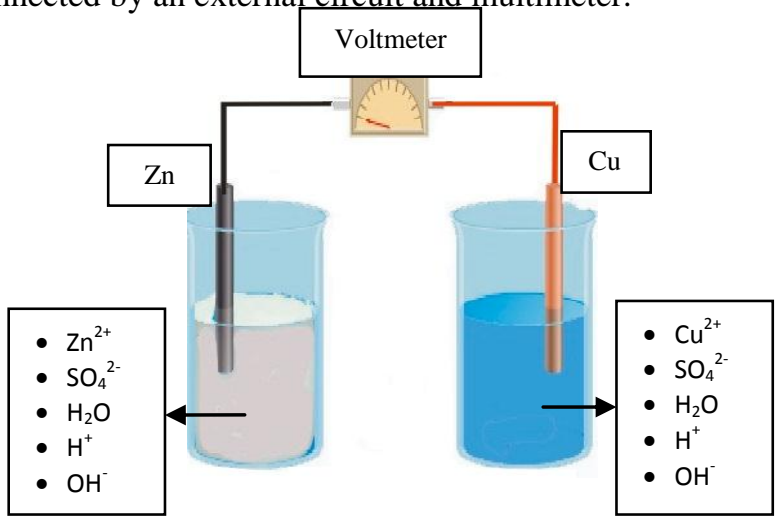

Fig. 6. Experiment 7

No potential difference is measured in multimeter. However, the $\mathrm{Cu}$ electrode looks a bit more polished.

Through mentors of researchers questions, students concluded that the system 7 only generates electrical current moment due to the non-neutrality of the charge electrolyte solution in the cell anode excess positive charge $(\mathrm{Zn} 2+)$ due to oxidation of zinc and electrolyte solution at the cathode excess negative charge $\left(\mathrm{SO}_{4}{ }^{2-}\right)$ due to the reduction of $\mathrm{Cu}^{2+}$.

There was one student who doubt the circuit which one is better to be used as a cell Volta between system 5 and 7 because he thinks Volta cell with an anode and a cathode in two separate containers is better than that only in one container. Another student said that system 7exists to address the shortcomings of system5, namely that $\mathrm{Cu}$ deposit formation only occurs at the cathode, but the concentration of the aqueous electrolyte solution, the system 5generates a longer electric current, whereas system 7only generates electrical current in a moment since the system 7 experienced partiality charge on the electrolyte solution, while the electrolyte solutionin system5remains neutral. This shows that at this stage, fellow students were able to provide interventions to achieve a balance of Cognitive(re-equilibrium).

\section{E. Treatment on Indicators 5}

Students conduct experiments 7 and 8 . In the experiment $8, \mathrm{Zn}$ electrode is dipped into a solution of $0.1 \mathrm{M} \mathrm{ZnSO4}$ and $\mathrm{Cu}$ electrode is dipped into a solution of $0.1 \mathrm{M} \mathrm{CuSO} 4$ in two different containers. Both electrodes are connected by an external circuit and multimeter. In between the electrolyte solution is applied salt bridge.

The blue color of $\mathrm{CuSO}_{4}$ solution is faded, metallic colored $\mathrm{Cu}$ is increasingly shiny, and the potential difference in the multimeter measured continuously. With 
the guidance of researchers through the questions, the students concluded that the negative ions of the salt bridge moves into the cell anode with excessive positive charge, while the positive ions of the salt bridge moves into the cell cathodes with excessive negative charge due to the higher concentration of the electrolyte solution in the salt bridge than the concentration electrolyte solution in both cell anode and cathode cells.

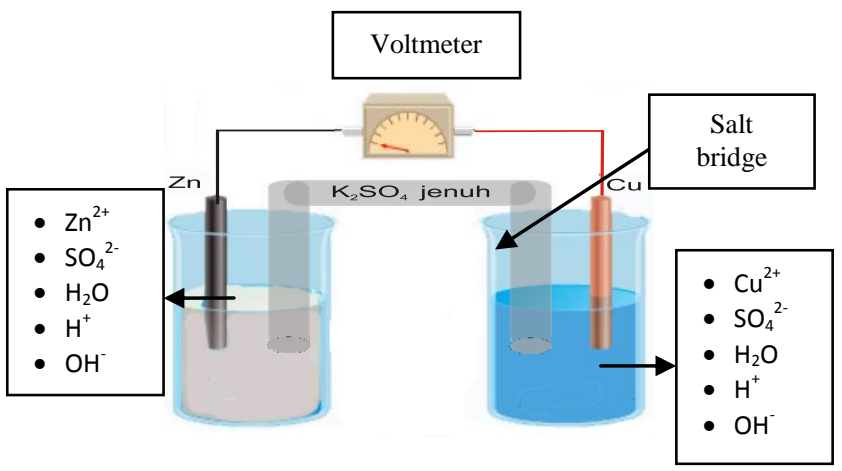

Fig. 7. Experiment 8

Some students argues that excessive $\mathrm{Zn} 2+$ ions at the anode cells cannot move to the cathode cell with excessive negative charge on cathode cell and excessive SO42-ions in cathode cell can not move to the anode cells that with excessive positive charge, while others said that such movement of ions possibly happen.

With the guidance of researchers through animated show, the students concluded that the function of the salt bridge is to facilitate the movement of ionic to make charge neutrality occurs in both cells. The most dominant mechanism of ion movement is the salt bridge towards the anode and cathode cells because the concentration of the electrolyte solution in the salt bridge is higher (saturated solution) compared to the concentration of the electrolyte solution in the cell anode and cathode. However, the movement of $\mathrm{Zn} 2+$ ions from anode cell to cathode cell or SO42- ion movement from the cathode to the anode cells may also occur.

In this indicator, students generally do not experience cognitive conflict situations because the observation resultsdo not contradict the theory they have learned. All students have understood since high school that the second electrode Volta cells are separated and applied salt bridge is a series of best Volta cells.

\section{F. Treatment at Indicator6}

Students conduct experiments 9. The series of trials is the same as the test series 8 , but with the positive pole multimeter connected with the anode and the negative pole to the cathode connected multimeter.

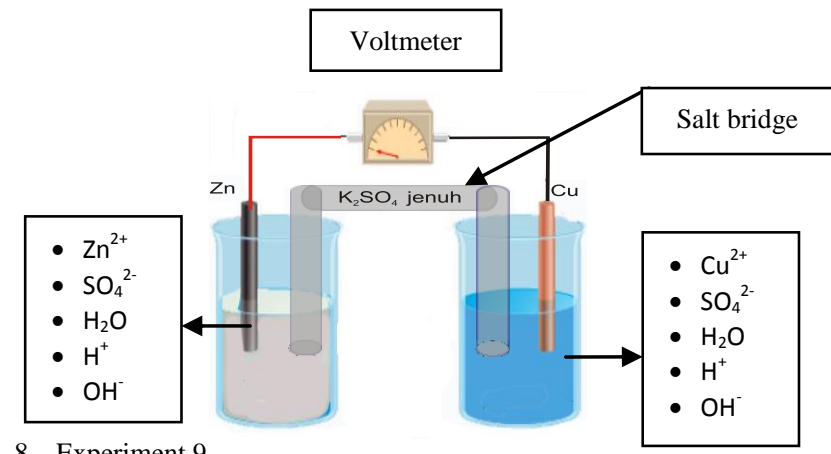

Fig. 8. Experiment 9
Some students wonder why the needle multimeteron moving to the left, not the right. This astonishment is one of the characteristics of cognitive conflict situations according to Lee (2001).

Researchers guide students conclude this phenomenon. If the anode is connected to the positive pole of a multimeter and a cathode connected to the negative pole multimeter (system 9), then the multimeter needle deviated to the left. However, if the anode is connected to the negative pole multimeter and a cathode connected to the positive pole multimeter (system 8), then the needle multimeter turns to the right. Based on this phenomenon, the students concluded that the anode in Volta cell is a negative pole, while the cathode is the positive pole.

Based on the questions of investigators' supervisor about the direction of the electrons in the Volta cell and physics convention regarding the direction of the flow of electrons, the students concluded that the anode in Volta cell is a negative pole, while the cathode in Volta cells is the positive pole and this can be proved through experiments.

\section{G. Students Conception Profile on End Ability Test}

Based on the figure 8 , usually students are in the category of identical fit and approximate fit. Only a small proportion of students who are in the category of incomplete fit.

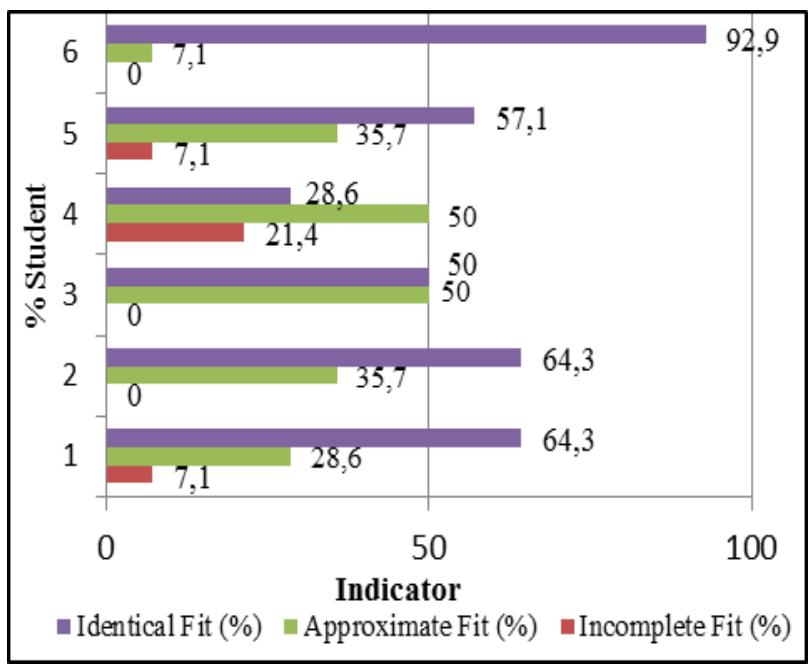

Fig. 9. Students Conception Profile on End Ability Test

\section{H. Change of Student Conception Profile Before and After Treatment}

Based on Table 1, it can be seen that generally students who are in the category of incomplete fit are more easily to change conception compared with students who are in the category of approximate fit. This is consistent with the statement of Appleton (1999) in Rolka (2007) that students who are in the category of approximate fit obtain new ideas, but still engage old ideas that have been previously acquired. 
1 ABLE I.

Change of Student Conception Profile

\begin{tabular}{|c|c|c|c|c|c|c|c|c|c|}
\hline \multirow{2}{*}{$\begin{array}{l}\text { In } \\
\text { di- } \\
\text { cat } \\
\text { or }\end{array}$} & \multicolumn{3}{|c|}{ Meningkat (\%) } & \multicolumn{3}{|c|}{ Tetap (\%) } & \multicolumn{3}{|c|}{ Menurun (\%) } \\
\hline & $\begin{array}{c}\operatorname{InF} \\
\overrightarrow{\mathbf{A F}}\end{array}$ & $\begin{array}{c}\text { InF } \\
\overrightarrow{\text { IdF }}\end{array}$ & $\begin{array}{c}\mathbf{A F} \\
\overrightarrow{\mathbf{I d F}}\end{array}$ & $\underset{\mathbf{I n F}}{\operatorname{InF}}$ & $\begin{array}{c}\mathbf{A F} \\
\overrightarrow{\mathbf{A F}}\end{array}$ & $\begin{array}{c}\text { IdF } \\
\overrightarrow{\text { IdF }}\end{array}$ & $\begin{array}{c}\text { AF } \\
\overrightarrow{\text { InF }}\end{array}$ & $\begin{array}{c}\text { IdF } \\
\overrightarrow{\mathrm{AF}}\end{array}$ & $\begin{array}{c}\text { IdF } \\
\overrightarrow{\text { InF }}\end{array}$ \\
\hline 1 & $\begin{array}{c}21 . \\
4\end{array}$ & 14.3 & 21.4 & 7.1 & 7.1 & 28.6 & 0 & 0 & 0 \\
\hline 2 & $\begin{array}{c}14 . \\
3\end{array}$ & 21.4 & 42.9 & 0 & 21.4 & 0 & 0 & 0 & 0 \\
\hline 3 & $\begin{array}{c}21 . \\
4\end{array}$ & 14.3 & 28.6 & 0 & 28.6 & 0 & 7.1 & 0 & 0 \\
\hline 4 & $\begin{array}{c}28 . \\
6\end{array}$ & 7.1 & 21.4 & 14.3 & 21.4 & 0 & 7.1 & 0 & 0 \\
\hline 5 & $\begin{array}{c}14 . \\
3\end{array}$ & 7.1 & 35.7 & 7.1 & 21.4 & 14.3 & 0 & 0 & 0 \\
\hline 6 & 0 & 57.1 & 21.4 & 0 & 7.1 & 14.3 & 0 & 0 & 0 \\
\hline
\end{tabular}

\section{CONCLUSION}

1. In the initial ability test, generally students are in the state of incomplete fit and approximate fitto all indicators. Only few of students who are in the state of identical fit.

2. The characteristic of cognitive conflict learning which can facilitate the change of student conception is a learning conditioning students to find imbalance between their prior knowledge with the acquired fact experiment, followed by teacher's intervention to enable the conflict situation result a new balance.

3. After acquiring the strategy learning of conflict cognitive, generally students increase their conception profile. However, there are some others who gain no change, even decreasing conception profile

\section{REFERENCES}

[1] Barker, V. (2004).Beyond Appearances: Students' Misconceptions about Basic Chemical Ideas, $2^{\text {nd }}$ edition. London: School of Education, Durham University.

[2] Dindar, Ayla C et al. (2010). What are the pre-service chemistry teachers' explanations on chemistry topics? The International Journal of Research in Teacher Eduacation, 1 (special issue), 3241.

[3] Duit, R. (2003). Conceptual Change: A powerful framework for improving science teaching and learning. International Journal of Science Education, 25(6), 671-688.

[4] Hergenhahn, B.R dan Olson, M.H.. (2009). Theories of Learning (Teori Belajar). Jakarta: Kencana.

[5] Khurshid, M., dan Iqbal, M.Z. (2009). Children's Misconseptions about Units on Changes, Acids and Laboratory Preparation of $\mathrm{CO}_{2}$, Bulletin of Education and Research. Desember 2009, 31(2), 61-74.

[6] Kutluay, Yasing. (2005). Diagnosis of Eleventh Grade Students' Misconceptions about Geometric Optic by a Three-Tier Test. Thesis pada The Graduate School of Natural and Applied Science.

[7] Lee, GyounghudanJaesool Kwon. (2001). What do We Know about Students' Cognitive Conflict in Science Classroom: a Theoretical Model of Cognitive Conflict Process.

[8] Lee, Gyounghu, dkk. (2003). Development of an instrument for measuring cognitive conflict in secondarylevel science classes.Journal of Reserach in Science Teaching, 40 (6), 585-603.

[9] Ozkaya, Ali Rizaet al. (2003). Prospective teachers' conceptual understanding of electrochemistry: Galvanic cell and electrolytic cell. The Royal Society of Chemistry, 7, 1-12.

[10] Rolka, K, Bettina Rosken, dan Peter Liljedahl. (2007). The Role of Cognitive Conflict in Belief Changes. Proceeding of 31st Conference of the International Group for the Psychology of Mathematics Education, 4, 121-128.

[11] Pinker. (2003). The Blank State:Modern Denial of Human Nature. Viking: Penguin Group.

[12] Posner, G.J., . (1982). Accommodation of a scientific conception: Towards a theory of conceptual change.Journal of Science Education, 66 (2), 211-227.
[13] Sanger, Michael J; Thomas J Greenbowe. (1999). An analysis of college chemistry textbooks as sources of misconceptions and errors in electrochemistry. Journal of Chemistry Education, 76 (6), 853-860.

[14] Toka, YurdagüldanPetek Askar. (2002). The effect of cognitive conflict and conceptual change text on students' achievement related to first degree equations with one unknown. HacettepeUniversitesiEgitimFakultesiDergisi, 23, 211-217. 